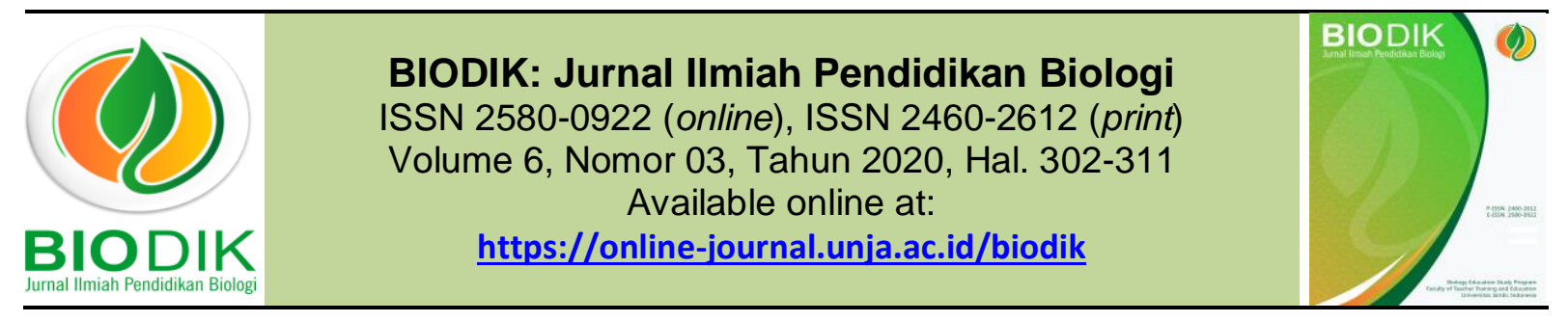

Research Article

open Access

\title{
Analisis Komponen Penyusun Lembar Kerja Siswa Biologi SMA Pada Praktikum Uji Enzim Katalase
}

\author{
(Analysis of the Students Worksheet Component of Senior High School Biology on \\ Catalase Enzyme Test Practicum)
}

\author{
Devi Deratama*, Sri Anggraeni, Bambang Supriatno \\ Universitas Pendidikan Indonesia, \\ JI. Dr. Setiabudhi No. 229 Bandung 40154, Indonesia \\ *Corresponding Author: devideratama@upi.edu
}

\begin{tabular}{|c|c|}
\hline Informasi Artikel & ABSTRACT \\
\hline $\begin{array}{l}\text { Submit: } 21-05-2020 \\
\text { Diterima: } 27-06-2020 \\
\text { Dipublikasikan: } 04-09-2020\end{array}$ & $\begin{array}{l}\text { Students Worksheet is a very important guide for doing work in the } \\
\text { laboratory which is often used by teachers and students. This study } \\
\text { aims to analyze the existence of the constituent components and to } \\
\text { provide an overview of the Students Worksheet Catalase Enzyme } \\
\text { Test contained in the High School Biology textbooks. The research } \\
\text { method used is descriptive qualitative method with a samples of } 8 \\
\text { Students Worksheet chosen by using purposive sampling technique. } \\
\text { The research instrument used was a LKS analysis instrument, table of } \\
\text { work step and rubric test results based on the Vee diagram. The } \\
\text { results showed that the Students Worksheet in terms of conceptual } \\
\text { analysis as a whole was not in accordance with the applicable } \\
\text { curriculum. For practical analysis as a whole it has shown quite good } \\
\text { results even though there are still some Students Worksheet whose } \\
\text { components are incomplete. Then the analysis of knowledge } \\
\text { construction shows that the knowledge construction process has not } \\
\text { been developed properly. In addition, from the results of the work step } \\
\text { test there are still problems as in the choice of sentence instructions } \\
\text { the steps of the work are less precise and less appropriate so that it } \\
\text { can confuse students in their execution. In terms of completeness and } \\
\text { component scores Students Worksheet based on the Vee Diagram, } \\
\text { only a small portion of the catalase enzyme student activity sheet did } \\
\text { not have the complete Vee Diagram component. Nevertheless, these } \\
\text { components have different qualities which are indicated by the } \\
\text { achievement scores of each component of Diagram Vee. Based on } \\
\text { these problems, the Catalyst Enzyme Test LKS requires an analysis } \\
\text { and improvement in terms of conceptual, procedural, and knowledge } \\
\text { construction. } \\
\text { Keywords Student Activity Sheet, Enzymes and Metabolism, } \\
\text { Catalase Enzyme Test }\end{array}$ \\
\hline Penerbit & ABSTRAK \\
\hline $\begin{array}{l}\text { Program Studi Pendidikan } \\
\text { Biologi, Fakultas Keguruan dan } \\
\text { Ilmu Pendidikan, Universitas } \\
\text { Jambi }\end{array}$ & $\begin{array}{l}\text { Lembar Kerja Siswa merupakan suatu pedoman yang sangat penting } \\
\text { untuk melakukan kerja di laboratorium yang sering digunakan oleh } \\
\text { guru dan siswa. Penelitian ini bertujuan untuk menganalisis } \\
\text { keberadaan komponen penyusun dan memberikan gambaran tentang } \\
\text { Lembar Kerja Siswa Uji Enzim Katalase yang terdapat pada buku } \\
\text { paket Biologi SMA. Metode penelitian yang digunakan adalah metode } \\
\text { deskriptif kualitatif dengan sampel penelitian berjumlah } 8 \text { LKS yang } \\
\text { dipilih dengan menggunakan teknik purposive sampling. Instrumen }\end{array}$ \\
\hline
\end{tabular}


penelitian yang digunakan adalah berupa instrument analisis LKS, tabel hasil uji langkah kerja dan rubrik berdasarkan diagram Vee. Hasil penelitian menunjukkan bahwa Lembar Kerja Siswa tersebut dari segi analisis konseptual secara keseluruhan kurang sesuai dengan kurikulum yang berlaku. Untuk analisis praktikal secara keseluruhan sudah menunjukkan hasil yang lumayan baik walaupun masih terdapat beberapa LKS yang komponennya belum lengkap. Kemudian analisis konstruksi pengetahuan menunjukkan bahwa proses konstruksi pengetahuan belum terbangun dengan baik. Selain itu, dari hasil uji langkah kerja masih terdapat permasalahan seperti dalam pemilihan kalimat instruksi langkah kerja yang kurang tepat dan kurang sesuai sehingga dapat membingungkan siswa dalam eksekusinya. Dari segi kelengkapan dan skor komponen LKS berdasarkan Diagram Vee, hanya sebagian kecil LKS enzim katalase yang tidak memiliki komponen Diagram Vee lengkap. Meskipun demikian, komponen-komponen tersebut memiliki perbedaan kualitas yang ditunjukkan oleh capaian skor dari masing-masing komponen Diagram Vee. Berdasarkan permasalahn tersebut, maka LKS Uji Enzim Katalase memerlukan sebuah analisis dan perbaikan dari segi konseptual, prosedural, maupun konstruksi pengetahuan.

Katakunci: Lembar Kerja Siswa (LKS), Enzim dan Metabolisme, Uji Enzim Katalase

This BIODIK : Jurnal IImiah Pendidikan Biologi is licensed under a CC BY-NC-SA (Creative Commons Attribution-ShareAlike 4.0 International License)

\section{PENDAHULUAN}

Praktikum merupakan suatu kegiatan yang menuntut siswa untuk melakukan pengamatan, percobaan atau pengujian suatu konsep atau prinsip materi pelajaran yang dilakukan di dalam atau di luar laboratorium. Dengan siswa melakukan suatu praktikum maka secara tidak langsung akan mengasah, mengembangkan, dan mengeksplorasi berbagai kemampuan dan keterampilan yang dimiliki oleh siswa, sehingga kemampuan dan keterampilan tersebut akan berguna bagi siswa di masa yang akan datang. Kegiatan praktikum dibutuhkan karena dapat memberikan pengalaman belajar secara nyata dan dapat mengembangkan keterampilan dasar bekerja di laboratorium (Gratia dalam Wahidah, 2018). Selain itu, Millar (dalam Wahidah, 2018) mengatakan bahwa kegiatan praktikum berperan untuk membantu siswa menghubungkan antara dua ranah pengetahuan, yaitu objek atau fenomena yang teramati dan ranah gagasan atau ide. Melalui kegiatan praktikum, siswa dilatih untuk mengembangkan kemampuan kognitif, afektif dan psikomotorik dalam memahami suatu fenomena biologi (Sudargo dan Asiah dalam Wahidah, 2018).

Untuk dapat menunjang kegiatan praktikum di dalam atau di luar laboratorium maka harus ada sebuah instruksi khusus atau sebuah pedoman untuk dapat melakukan suatu percobaan, pengamatan atau pembuktian terhadap sesuatu agar siswa dapat mengkonstruk pengetahuannya. Instruksi khusus atau pedoman tersebut salah satunya adalah Lembar Kerja Siswa (LKS). Lembar Kerja Siswa, atau penuntun kegiatan praktek merupakan suatu fenomena yang saat ini dianggap penting, sebagai kelengkapan untuk buku yang diterbitkan dan mencantumkan label 
sesuai dengan kurikulum. Lembar Kerja Siswa merupakan Desain Kegiatan Laboratorium (DKL) yang menuntun siswa untuk melaksanakan kegiatan praktek sains (Supriatno, 2018).

LKS atau DKL menjadi sangat penting karena itu merupakan suatu pedoman untuk melakukan kerja di laboratorium. Tetapi sayangnya Lembar Kerja Siswa (LKS) yang beredar masih banyak yang tidak sesuai dan kurang mengembangkan, memfasilitasi dan mengeksplorasi berbagai kemampuan dan keterampilan yang dimiliki oleh siswa. Berdasarkan temuan peneliti, seringkali Lembar Kerja Siswa (LKS) tidak sesuai dengan permintaan kurikulum khususnya dalam Kompetensi Dasar (KD), tujuan yang ingin dicapai, alat dan bahan yang digunakan, langkah kerja yang dilakukan serta pertanyaan yang di munculkan di dalam praktikum. Temuan ini juga diperkuat oleh penelitian yang dilakukan Supriatno (2009) yang menyatakan bahwa hanya 24\% DKL yang dapat dikerjakan dengan hasil sesuai prosedur dan tuntas dari segi analisis data dan penarikan kesimpulan. Kemudian Supriatno (dalam Supriatno, 2013) berdasarkan hasil analisis awal Desain Kegiatan Laboratorium dalam bentuk LKS mengenai tujuan, pendekatan dan prosedur serta materi, ditemukan bahwa: (1) tujuan kegiatan laboratorium lebih banyak menekankan aspek kognitif untuk meningkatkan konsep, sementara aspek psikomotor untuk mengembangkan keterampilan dasar laboratorium sebagai bekal pada tingkat lanjut kurang dikembangkan; (2) sebagian besar dilakukan pendekatan deduktif dengan metode ekspositori. Ekspositori sering disebut juga dengan verifikasi atau confirmatory; (3) dari aspek prosedur, pada umunya hampir semua langkah dituntun seperti melaksanakan kegiatan pada resep masakan, hampir tidak ada langkah yang dikembangkan sendiri oleh siswa dan (4) dari aspek pemilihan materi, kegiatan laboratorium yang dikembangkan tidak mempertimbangkan esensi, kesesuaian, kedalaman dan kompleksitasnya.

Salah satu diantara materi Biologi yang memiliki potensi untuk dikembangkan melalui kegiatan praktikum adalah materi Enzim dan Metabolisme. Materi enzim dan metabolisme khususnya memiliki kompleksitas yang cukup rumit di dalam memahami materinya. Hal ini tentu karena enzim dan metabolisme merupakan suatu reaksi yang terjadi di dalam sel dan tidak dapat diamati proses dan produk yang dihasilkannya dengan kasat mata. Untuk mengamati produk hasil enzim pada khususnya dapat diamati melalui praktikum enzim katalase. Uji tersebut dapat diterapkan dalam kegiatan praktikum di sekolah khususnya di sekolah jenjang SMA. Namun peneliti masih menemukan adanya ketidaksesuaian atau kekurangan dari praktikum tersebut. Kesulitan memahami konsep biologi terletak pada materi yang disampaikan, apabila di bantu dengan praktikum siswa akan lebih memahami dan mengenal tentang materi yang dipelajari, karena dengan belajar tentang suatu materi kemudian dilakukan suatu pembuktian melalui praktikum siswa cenderung akan lebih memahami konsep tersebut daripada hanya menghafalnya saja. Secara umum, penelitian ini bertujuan untuk memberikan gambaran keadaan dan menjelaskan hasil analisis kegiatan laboratorium, uji coba langkah kerja dan analisis kelengkapan 
komponen Diagram Vee pada Lembar Kerja Siswa (LKS) Uji Enzim Katalase yang terdapat pada buku paket Biologi SMA.

\section{METODE PENELITIAN}

Metode penelitian yang digunakan dalam penelitian ini adalah deskriptif kualitatif, karena bertujuan untuk menggambarkan fenomena-fenomena yang ditemukan. Penelitian ini diupayakan dapat memberikan gambaran mengenai keadaan Lembar Kerja Siswa (LKS) praktikum enzim katalase yang digunakan di jenjang SMA. Sampel yang diambil dalam penelitian ini adalah 8 buah Lembar Kerja Siswa (LKS) dari Kurikulum Tingkat Satuan Pendidikan (KTSP) dan Kurikulum 2013 (Kurtilas) mulai dari tahun 2006 sampai tahun 2016. Dari 8 LKS tersebut, 2 LKS diantaranya disusun untuk memenuhi tuntutan kompetensi dasar di KTP 2006. Teknik sampling yang digunakan adalah secara purposive sampling. Instrumen penelitian yang digunakan adalah berupa tabel hasil analisis konseptual, analisis praktikal, analisis konstruksi pengetahuan, tabel hasil uji langkah kerja, tabel keberadaan komponen diagram Vee, dan tabel penskoran diagram Vee yang diadaptasi dari Novak dan Gowin (1984). Data yang diperoleh dari rubrik kelengkapan komponen LKS dan rubrik penskoran komponen LKS berdasarkan Diagram Vee kemudian diolah ke dalam bentuk persentase (\%).

Analisis pertama pada Lembar Kerja Siswa (LKS) enzim katalase yang telah diambil dari sekolah yaitu dengan membaca, memahami, dan melakukan uji langkah kerja tanpa ada perubahan susunan langkah kerja (manipulasi). Selain itu analisis juga dilakukan terhadap komponen sebuah LKS seperti Kompetensi Dasar, tujuan pembelajaran, landasan teori, alat dan bahan, serta pertanyaan yang dimunculkan.

\section{HASIL DAN PEMBAHASAN}

\section{Analisis Konseptual, Analisis Praktikal dan Analisis Konstruksi Pengetahuan Lembar Kerja Siswa (LKS) Enzim Katalase}

Analisis menggunakan instrumen yang dikembangkan sudah melalui tahap verifikasi dan validasi oleh dosen ahli bidangnya yang meliputi analisis konseptual yang bertujuan untuk menganalisis kesesuaian kegiatan laboratorium dengan kurikulum yang berlaku, analisis praktikal yang bertujuan untuk menguji keterlaksanaan kegiatan secara laboratorium dalam menghadirkan objek/fenomena, dalam hal ini uji coba tanpa perubahan alat, bahan dan prosedur dan analisis konstruksi pengetahuan yang merupakan proses kontruksi pengetahuan, yang dibentuk berdasarkan objek/fenomena yang muncul, dicatat dan digunakan untuk mengkontruksi pengetahuan.

Berdasarkan hasil analisis dari 6 LKS enzim katalase pada Kurikulum 2013 dapat diambil kesimpulan bahwa dari segi analisis konseptual masih banyak terdapat permasalahan misalnya seperti judul praktikum belum sesuai dengan langkah kerja 
sehingga tidak adanya relevansi diantara keduanya, tujuan praktikum tidak terdapat di dalam praktikum, dan tingkat kognitif yang dimunculkan hanya bersifat konfirmasi saja dari apa yang telah siswa lakukan, tidak mengembangkan kemampuan berpikir tingkat tinggi sesuai dengan tuntutan Kurikulum 2013 dan kurang membangun pengetahuan siswa.

Selain itu dari segi analisis praktikal yang bertujuan untuk menguji keterlaksanaan kegiatan secara laboratorium dalam menghadirkan objek/fenomena, dalam hal ini uji coba tanpa perubahan alat, bahan dan prosedur sudah menunjukkan hasil yang baik walaupun masih terdapat beberapa kekurangan diantaranya seperti yang terlampir pada tabel 1 berikut.

Tabel 1. Hasil Analisis Praktikal pada LKS Enzim Katalase

\begin{tabular}{lll}
\hline No & Parameter & Hasil Analisis \\
\hline 1. & Bahan praktikum & $\begin{array}{l}\text { Pada beberapa LKS, konsentrasi larutan yang digunakan tidak } \\
\text { dicantumkan. }\end{array}$ \\
\hline 2. & Prosedur praktikum & $\begin{array}{l}\text { Ada beberapa LKS dalam langkah kerja tidak dilakukan pengujian } \\
\text { nyala bara api terhadap gelembung gas yang dihasilkan. }\end{array}$ \\
\hline 3. & $\begin{array}{l}\text { Bentuk perekaman } \\
\text { data }\end{array}$ & $\begin{array}{l}\text { Ada beberapa LKS yang tabel pengamatan praktikumnya tidak } \\
\text { diberikan keterangan dalam pengisiannya sehingga akan membuat } \\
\text { siswa menjadi kebingungan dan tidak terarah. }\end{array}$ \\
\hline 4. & Objek/ fenomena & $\begin{array}{l}\text { Ada sebagian LKS yang objek/ fenomena yang munculnya tidak } \\
\text { relevan dengan tujuan praktikum. }\end{array}$ \\
\hline 5. & Alokasi waktu & $\begin{array}{l}\text { Hampir semua LKS enzim katalase tidak terdapat alokasi waktu } \\
\text { yang seharusnya menjadi acuan siswa kerja laboratorium. }\end{array}$ \\
\hline 6. & Petunjuk safety lab & $\begin{array}{l}\text { Hampir semua LKS tidak adanya petunjuk safety lab yang } \\
\text { membuat siswa lebih terarah dan hati-hati dalam melakukan } \\
\text { praktikum, karena praktikum enzim katalase ini berhubungan } \\
\text { dengan larutan yang bersifat korosif dan menggunakan api juga } \\
\text { dalam praktikumnya. }\end{array}$ \\
\hline
\end{tabular}

Dari segi analisis konstruksi pengetahuan yang dilakukan juga masih terdapat beberapa permasalahan, diantaranya seperti pertanyaan umumnya hanya menanyakan fakta, sangat sederhana dan hanya jenjang kognitif C2 saja, ada juga pertanyaan yang dapat dijawab melalui studi literatur tanpa harus melakukan praktikum. Pertanyaan tidak mengarahkan siswa untuk mengkonstruksi konsep, memunculkan suatu prinsip dan analisis tidak muncul. Penarikan kesimpulan berdasarkan data yang direkam secara keseluruhan juga tidak ada.

Kemudian berdasarkan hasil analisis dari 2 LKS enzim katalase pada Kurikulum Tingkat Satuan Pendidikan (KTSP) 2006 dapat diambil kesimpulan bahwa dari segi analisis konseptual permasalahan yang terjadi secara keseluruhan hampir sama dengan LKS enzim katalase yang terdapat pada Kurikulum 2013, hanya saja permasalahan yang mencolok terdapat pada analisis praktikal dan analisis konstruksi pengetahuan. Pada analisis praktikal masalah yang sangat nyata adalah tidak adanya bentuk perekaman data, padahal dengan adanya bentuk data yang di transformasikan dapat membantu siswa dalam membangun atau mengkonstruk 
pengetahuannya sendiri. Kemudian dalam analisis konstruksi pengetahuan masalah yang nyata adalah dalam bentuk pertanyaan yang ada sangat tidak repsesentatif, sederhana dan hanya 2 pertanyaan saja yang dimunculkan dan itu tidak bisa dijawab dengan melakukan praktikum, tetapi harus mencari dengan studi literatur.

\section{Hasil Uji Langkah Kerja}

Hasil analisis dan uji coba menunjukkan bahwa masih terdapat permasalahan pada langkah kerja yang terdapat pada LKS enzim katalase di jenjang SMA. Permasalahan yang terjadi pada saat uji langkah kerja ini terjadi akibat pemilihan kalimat instruksi langkah kerja yang kurang tepat dan kurang sesuai sehingga makna kalimatnya membingungkan (Wahidah, 2018). Temuan ini sesuai dengan penelitian Supriatno (2013) yang menyatakan bahwa prosedur praktikum meskipun rinci, beberapa di antaranya tidak terstruktur dan perintahnya membingungkan sehingga menimbulkan penafsiran ganda. Masalah yang muncul diantaranya di lampirkan pada tabel 2 .

\section{Tabel 2. Tabel Hasil Analisis Permasalahan Uji Langkah Kerja}

\begin{tabular}{ll}
\hline No. Instruksi langah kerja yang \\
bermasalah
\end{tabular}

Tambahkan $\mathrm{HCl}$ sebanyak 10 tetes ke dalam tabung reaksi $\mathrm{B}$, kemudian ukur $\mathrm{pH}$ larutan.

3. Tambahkan $\mathrm{NaOH}$ sebanyak 10 tetes ke dalam tabung reaksi $\mathrm{C}$, kemudian ukur pH larutan.

4. Letakkan tabung reaksi $\mathrm{D}$ ke dalam gelas beker yang berisi air panas, kemudian ukur suhunya.

5. Letakkan tabung reaksi $\mathrm{E}$ ke dalam gelas beker yang berisi es batu, kemudian ukur suhunya.

6. Siapkan larutan $\mathrm{H}_{2} \mathrm{O}_{2}$ pada tabung reaksi I, II, III, IV, V (masing-masing setinggi $0,5 \mathrm{~cm}$ tabung reaksi). Perhatian: Hindarkan kulit Anda dari larutan dan busa $\mathrm{H}_{2} \mathrm{O}_{2}$ karena dapat
Rekonstruksi permasalahan hasil uji langkah kerja

Sebaiknya dalam pemberian nama pada tabung reaksi jangan hanya menggunakan kode $A$ atau B saja, tetapi harus dijelaskan juga, misalnya $A$ untuk ekstra hati asli, B untuk ekstrak hati + HCL, C untuk ekstrak hati $+\mathrm{NaOH}, \mathrm{D}$ untuk ekstrak hati di dalam air panas dan $E$ untuk ekstrak hati di es batu.

Tidak dijelaskan atau dicantumkan berapa lama waktu yang dibutuhkan dalam pemberian $\mathrm{HCl}$ dari awal pemberian treatment sampai dengan pemberian $\mathrm{H}_{2} \mathrm{O}_{2}$ dan pengetesan dengan menggunakan nyala bara api.

Tidak dijelaskan atau dicantumkan berapa lama waktu yang dibutuhkan dalam pemberian $\mathrm{NaOH}$ dari awal pemberian treatment sampai dengan pemberian $\mathrm{H}_{2} \mathrm{O}_{2}$ dan pengetesan dengan menggunakan nyala bara api.

Tidak dicantumkan berapa lama ekstrak hati dimasukkan ke dalam air panas sampai dengan pemberian $\mathrm{H}_{2} \mathrm{O}_{2}$ dan pengetesan dengan menggunakan nyala bara api.

Tidak dicantumkan juga berapa lama ekstrak hati dimasukkan ke dalam es batu sampai dengan pemberian $\mathrm{H}_{2} \mathrm{O}_{2}$ dan pengetesan dengan menggunakan nyala bara api.

Pada langkah nomor 7 sebaiknya diganti dengan "Siapkan larutan $\mathrm{H}_{2} \mathrm{O}_{2}$ pada gelas beker ukuran minimal $50 \mathrm{ml}$ dan pipet tetes". 
menyebabkan iritasi dan rasa gatal.

7. Tuangkan $\mathrm{H}_{2} \mathrm{O}_{2}$ dari tabung reaksi I ke dalam ekstrak hati pada tabung reaksi A dan segera lakukan uji gelembung gas dengan menggunakan lidi yang membara.

Pada langkah nomor 8 sebaiknya diganti dengan
"Teteskan 10 tetes larutan $\mathrm{H}_{2} \mathrm{O}_{2}$ ke dalam ekstrak
hati pada tabung $\mathrm{A}$ yang berisi ekstrak hati asli,
segera tutuplah dengan ibu jari kanan dan
amatilah jumlah gelembung yang dihasilkan
kemudian segera lakukan uji gelembung gas
dengan menggunakan arang lidi yang dibakar
dan masih merah membara.

Pada langkah nomor 8 sebaiknya diganti dengan "Teteskan 10 tetes larutan $\mathrm{H}_{2} \mathrm{O}_{2}$ ke dalam ekstrak hati pada tabung $\mathrm{A}$ yang berisi ekstrak hati asli, segera tutuplah dengan ibu jari kanan dan amatilah jumlah gelembung yang dihasilkan kemudian segera lakukan uji gelembung gas dan masih merah membara.

\section{Analisis Kelengkapan dan Skor Komponen Lembar Kerja Peserta Didik (LKPD) Berdasarkan Diagram Vee}

Berdasarkan hasil analisis keberadaan komponen diagram Vee yang terdapat pada LKS enzim katalase (Tabel 3) menunjukkkan bahwa komponen yang umum muncul pada LKS enzim katalase yaitu pada pertanyaan focus, objek/ peristiwa, dan catatan/ transformasi. Sedangkan komponen diagram Vee yang umumnya belum muncul yaitu pada konsep/ prinsip/ teori dan klaim pengetahuan. Hal ini terjadi karena tidak adanya landasan teori, konsep atau prinsip di bagian LKS tersebut. Padahal dengan adanya pendahuluan tentang landasan teori pada sebuah praktikum maka akan lebih mengarahkan siswa untuk lebih paham tentang apa yang mereka kerjakan, siswa menjadi lebih tertarik dan tertantang untuk bisa melaksanakan praktikum tersebut. dan tentunya harapan dari sebuah praktikum akan terwujud dengan baik. Selain itu tidak adanya klaim pengetahuan di dalam suatu LKS maka apa yang menjadi landasan dalam suatu praktikum tidak akan terwujud dengan baik. Dengan adanya klaim pengetahuan tentunya hasil akhir dari suatu praktikum akan terlihat sangat jelas, bahwasannya praktikum itu memiliki hakikat untuk bisa mengkonstruk pengetahuan. Selain itu praktikum juga bertujuan untuk membangun konsep yang baru atau memantapkan konsep yang sudah dimiliki oleh siswa. Dari hal tersebut sudah sangat jelas bahwa klaim pengetahuan adalah salah satu komponen yang penting dalam suatu LKS. LKS yang baik adalah LKS yang memiliki semua komponen esensial seperti halnya komponen yang ada dari suatu diagram Vee.

Tabel 3. Persentase Keberadaan Komponen Diagram Vee

\begin{tabular}{lll}
\hline No & Komponen Diagram Vee & Persentase (\%) \\
\hline 1. & Pertanyaan fokus & 100 \\
\hline 2. & Objek/ peristiwa & 100 \\
\hline 3. & Konsep/ prinsip/ teori & 37,5 \\
\hline 4. & Catatan/ transformasi & 75 \\
\hline 5. & Klaim pengetahuan & 37,5 \\
\hline
\end{tabular}

Setelah dilakukan analisis terkait keberadaan komponen diagram Vee, selanjutnya dilakukan pula penskoran setiap komponen diagram Vee. Hasil temuan pada Tabel 4 menunjukkan bahwa meskipun pada LKS enzim katalase sudah terdapat komponen diagram Vee, namun skor yang didapatkan oleh setiap 
komponennya masih rendah. Komponen pertanyaan fokus dan objek/ peristiwa memiliki skor maksimum 3, sementara komponen konsep/ prinsip/ teori, catatan/ transformasi dan klaim pengetahuan memiliki skor maksimum 4.

Tabel 4. Persentase Penskoran Setiap Komponen Diagram Vee

\begin{tabular}{|c|c|c|c|}
\hline No & Komponen Diagram Vee & Skor & Persentase (\%) \\
\hline \multirow{4}{*}{1.} & \multirow{4}{*}{ Pertanyaan fokus } & 0 & 0 \\
\hline & & 1 & 25 \\
\hline & & 2 & 25 \\
\hline & & 3 & 50 \\
\hline \multirow{4}{*}{2.} & \multirow{4}{*}{ Objek/ peristiwa } & 0 & 0 \\
\hline & & 1 & 37,5 \\
\hline & & 2 & 0 \\
\hline & & 3 & 62,5 \\
\hline \multirow{5}{*}{3.} & \multirow{5}{*}{ Konsep/ prinsip/ teori } & 0 & 25 \\
\hline & & 1 & 62,5 \\
\hline & & 2 & 0 \\
\hline & & 3 & 12,5 \\
\hline & & 4 & 0 \\
\hline \multirow{5}{*}{4.} & \multirow{5}{*}{ Catatan/ transformasi } & 0 & 25 \\
\hline & & 1 & 0 \\
\hline & & 2 & 0 \\
\hline & & 3 & 50 \\
\hline & & 4 & 25 \\
\hline \multirow{5}{*}{5.} & \multirow{5}{*}{ Klain pengetahuan } & 0 & 0 \\
\hline & & 1 & 37,5 \\
\hline & & 2 & 0 \\
\hline & & 3 & 62,5 \\
\hline & & 4 & 0 \\
\hline
\end{tabular}

Persentase perolehan skor pertanyaan focus pada LKS enzim katalase sudah menunjukkan skor yang ideal (skor 3 ) dan memiliki persentase $50 \%$ dimana terdapat 4 LKS yang memiliki skor 3, artinya masalah yang akan dikaji tersirat dalam tujuan atau komponen lain dalam LKPD, maupun tersurat dalam rumusan masalah. Hal ini tentu akan memudahkan dalam menentukan kemana arah permasalahan ini mau dibawa. Pertanyaan fokus yang jelas dapat diidentifikasi; meliputi konsep yang akan digunakan serta mendukung peristiwa utama dan dapat memperkuat objek. LKS yang memiliki pertanyaan fokus menandakan bahwa LKS tersebut mampu mengarahkan peserta didik untuk memperoleh apa yang seharusnya mereka temukan dalam kegiatan laboratorium (Millar \&Abraham, 2009), meskipun pertanyaan fokus pada beberapa LKS enzim katalase belum memperoleh skor maksimum. Adapun pertanyaan-pertanyaan fokus di LKS tersebut dapat ditemukan secara jelas di tujuan praktikum ataupun secara tersirat di judul praktikum.

Untuk objek/ peristiwa, persentase perolehan skor pada LKS enzim katalase sudah menunjukkan skor yang ideal (skor 3 ) dan memiliki presentase $62,5 \%$ dimana terdapat 5 LKS yang memiliki skor 3 yang artinya secara keseluruhan LKS enzim 
katalase ini dapat memunculkan objek/ peristiwa atau fakta yang akan diteliti dan artinya objek dapat diidentifikasi, konsisten dengan pertanyaan focus dan juga mendukung dengan apa yang akan ditulis.

Untuk konsep/ prinsip/ teori, persentase perolehan skor pada LKS enzim katalase belum menunjukkan skor ideal dan masih menunjukkan skor 1, memiliki presentase sebesar $62,5 \%$ dimana terdapat 5 LKS yang memiliki skor 1 yang artinya secara umum LKS enzim katalase ini belum terdapat teori, prinsip serta konsep atau sedikit konsep yang dapat diidentifikasi, tetapi tanpa prinsip-prinsip serta teori, atau sebuah prinsip yang tertulis merupakan pengetahuan yang diperoleh dari kegiatan laboratorium. Padahal menurut temuan Swarmi, et. al. (2006) menyatakan bahwa teori, prinsip serta konsep dapat memberikan dasar pada siswa untuk mengkonstruk pengetahuan barunya atau sebagai dasar untuk pembelajaran lebih lanjut. Teori, prinsip dan konsep ini juga akan menunjang proses pencatatan data serta transformasi data, karena pemahaman mengenai teori, prinsip serta konsep merupakan pengetahuan awal yang akan membantu dan mengarahkan siswa untuk lebih mudah mengorganisasi data yang didapatkan sehingga data yang didapatkan dapat menunjang pembentukan klaim pengetahuan (Wahidah, 2018).

Untuk catatan/ transformasi, persentase perolehan skor pada LKS enzim katalase belum menunjukkan skor ideal masih menunjukkan skor 3 , memiliki presentase sebesar $50 \%$ dimana terdapat 4 LKS yang memiliki skor 3 , yang artinya kegiatan pencatatan dapat diidentifikasi dan sesuai dengan peristiwa utama tetapi transformasi tidak konsisten dengan pertanyaan fokus.

Untuk klaim pengetahuan, presentase perolehan skor pada LKS enzim katalase belum menunjukkan skor ideal, masih menunjukkan skor 3, memiliki presentase sebesar $62,5 \%$ dimana terdapat 5 LKS yang memiliki skor 3, yang artinya bahwa klaim pengetahuan yang dibentuk mengandung konsep-konsep yang sesuai dengan pertanyaan fokus dan hasil pencatatan dan transformasi, tetapi belum mengarah kepada pembentukan pertanyaan fokus baru

\section{KESIMPULAN}

Berdasarkan hasil analisis dan uji coba peneliti terhadap Lembar Kerja Siswa (LKS) uji enzim katalase pada buku paket tersebut, dapat disimpulkan bahwa masih terdapat beberapa permasalahan yang ditemukan pada saat analisis dan uji coba langkah kerja Lembar Kerja Siswa (LKS) uji enzim katalase. Temuan menunjukkan bahwa Lembar Kerja Siswa (LKS) tersebut dari segi analisis konseptual secara keseluruhan masih terdapat banyak permasalahan dimana kegiatan praktikum yang dilakukan kurang sesuai dengan kurikulum yang berlaku. Untuk analisis praktikal secara keseluruhan sudah menunjukkan hasil yang lumayan baik walaupun masih terdapat beberapa LKS yang komponennya belum lengkap dan belum ada. Kemudian analisis konstruksi pengetahuan menunjukkan bahwa proses konstruksi pengetahuan belum terbangun dengan baik. Selain itu, dari hasil uji langkah kerja masih terdapat permasalahan seperti dalam pemilihan kalimat instruksi langkah kerja 
yang kurang tepat dan kurang sesuai sehingga dapat membingungkan siswa dalam eksekusinya. Dari segi kelengkapan dan skor komponen LKS berdasarkan Diagram Vee, hanya sebagian kecil LKS enzim katalase yang tidak memiliki komponen Diagram Vee lengkap. Meskipun demikian, komponen-komponen tersebut memiliki perbedaan kualitas yang ditunjukkan oleh capaian skor dari masing-masing komponen Diagram Vee. Kemudian berdasarkan kesimpulan dari hasil penelitian yang telah dilakukan, saran dari peneliti untuk kesempurnaan penelitian selanjutnya bahwa dalam menganalisis suatu kegiatan praktikum hendaknya harus mengambil banyak sumber yang di analisis, agar kelebihan dan kekurangan suatu praktikum dari masing-masing sumber dapat dikombinasikan dengan baik sehingga menghasilkan suatu Lembar Kerja Siswa (LKS) yang teruji.

\section{DAFTAR PUSTAKA}

Baedowi, Ahmad. (2015). Manajemen Sekolah Efektif: Pengalaman Sekolah Sukma Bangsa. Jakarta: Pustaka Alvabet.

Djamarah, S. B dan Aswan Zain. (2006). Strategi Belajar Mengajar. Jakarta: PT Rineka Cipta.

Kruea-In Chatchai, Nantarat Kruea-In, and Witat Fakcharoenpholb. (2015). A Study of Thai In-Service and Pre-Service Science Teachers' Understanding of Science Process Skills. Procedia - Social and Behavioral Sciences 197, 993 997.

Laelasari, Iseu dan Bambang Supriatno. (2018). Analisis Komponen Penyusun Desain Kegiatan Laboratorium Bioteknologi. Jurnal Bioedukatika. 6(2), 84 - 90.

Millar, R., \& Abrahams, I. (2009). Practical Work: Making It More Effective. School Science Review, 59-64.

Millar, R. (2004). The Role of Practical Work in The Teaching and Learning of Science. Washington DC. National Academy of Sciences.

Rini, Annisa Setya. (2013). Analisis Relevansi Desain Kegiatan Laboratorium Terhadap Kompetensi Dasar dalam Konsep Protista. Skripsi Jurusan Pendidikan Biologi FPMIPA UPI: Tidak diterbitkan.

Supriatno, B. (2009). Uji Langkah Kerja Laboratorium Sekolah. Proseding Seminar Nasional Biologi: Inovasi dan Pendidikan Biologi dalam Pengembangan Sumber Daya Manusia, 255-261.

Supriatno, B. (2013). Pengembangan Program Perkuliahan Pengembangan Praktikum Biologi Sekolah Berbasis ANCORB untuk Mengembangkan Kemampuan Merancang dan Mengembangkan Desain Kegiatan Laboratorium. Disertasi Jurusan Pendidikan Biologi FPMIPA UPI: Tidak diterbitkan.

Swami \& Shields. (2006). Gowin's Knowledge Vee: Using To Improve Preservice Teachers Ability for Conducting and Directing Science. University of Cincinnati.

Wahidah, Nur Sopiah, Bambang Supriatno, dan Mimin Nurjhani Kusumastuti. (2018). Analisis Struktur dan Kemunculan Tingkat Kognitif pada Desain Kegiatan Laboratorium Materi Fotosintesis. Assimilation: Indonesian Journal of Biology Education, 1(2), 70-76. 